\title{
The Acute Consciousness of Clients Fathoming Level Encompassing Product Content Inscriptions Leading to Their Purchase Decisions: Empirical Evidence from Ho Town
}

\author{
Aphu Elvis Selase1, Xinhai Lu¹, Akhayie Mamat Abdoulaye², Afenya Millicent Selase3, \\ Akunda Doreen ${ }^{1}$, Muganga Emmanuel ${ }^{1}$, Rhoda Obiokor Amoo' \\ ${ }^{1}$ College of Public Administration, Huazhong University of Science and Technology, Wuhan, China \\ ${ }^{2}$ Department of Land Resource Management, China University of Geosciences, Wuhan, China \\ ${ }^{3}$ Department of Accounting, Zhongnan University of Economics and Law, Wuhan, China \\ Email: I201722111@hust.edu.cn, elvis.qapito@yahoo.com
}

How to cite this paper: Selase, A. E., Lu, X. H., Abdoulaye, A. M., Selase, A. M., Doreen, A., Emmanuel, M., \& Amoo, R. O. (2018). The Acute Consciousness of Clients Fathoming Level Encompassing Product Content Inscriptions Leading to Their Purchase Decisions: Empirical Evidence from Ho Town. Psychology, 9, 3007-3025. https://doi.org/10.4236/psych.2018.915175

Received: November 20, 2018 Accepted: December 24, 2018 Published: December 27, 2018

Copyright $\odot 2018$ by authors and Scientific Research Publishing Inc. This work is licensed under the Creative Commons Attribution International License (CC BY 4.0).

http://creativecommons.org/licenses/by/4.0/

\section{Abstract}

Consumers of a product should not only be concerned about the product package, design and its model but most importantly should be concerned about the ingredients that come into play in making these products. This research was undertaken to study the consciousness of consumers of product contents on product labels, before, during and after consumption. The objectives of this research were to find out whether customers pay attention to the inscriptions of product content information on product labels, and also find out customers understanding of product content labelled on product. The convenience sampling technique was used in selecting the sample of 100 (hundred) customers from the population considering the large number of consumable products consumers in Ho. Respondents were interrogated using questionnaire. Computer data analysis Statistical Package for the Social Sciences (SPSS) was employed to analyse the data in order to help interpret results. It was discovered during this research that more than half of the sample size have knowledge about the product content inscription. It was also found out that just a little below majority buy any product that is packaged. The high percentage disagree to the proposition that once a product is packaged it is fit to buy. Contradictory to the general perception that people do not bother about content inscriptions on product labels, this research proves otherwise. In the nutshell, it was recommended that Health Regulatory bodies, National Commission for Civic Education, Food and Drug Board Authority, Ghana Standard Authority, Consumer Protection groups, Association of Ghana Industries and Chartered Institute of Marketing Ghana should take up 
a mantle to make the public aware through means like social media, print media, and telecommunication media.

\section{Keywords}

Acute, Consciousness, Clients, Decisions, Encompassing, Fathoming, Ho, Inscriptions, Purchase

\section{Background of the Study}

Today with rapid development, marketing communications are also growing. One of the marketing communication tools used by the marketers is attractive product packaging and labelling to increase their product sales. This is very popular nowadays and involves a number of factors working behind it. Packaging helps the marketers to glamorize their product so that they can get instant response from consumers. Visual representation is the most tactic strategy as everyone is comfortable with what they see as compared to other responses. An old proverb: "We are what we eat" signifies that people are not only attracted towards packaging but are also conscious about the product quality and hence nutritional labelling comes into play. Labelling communicates to consumers that the product holds those attributes that can fill the required need and fulfils the best as compared to the other brands of the same product category. Nutritional labelling provides the customers with the opportunity to choose healthier food for themselves and their families. Due to the increasing number of health hazards, every age group person wants to know what is healthy for him. Mothers are more protective about their children health and growth, similarly labels provide old age people with the option to consume necessary nutrient requirements for their body.

Since Stanton R Avery manufactured the world's first self-adhesive labels and made it into successful business in 1930's, labelling has become mandatory for all packaged consumer products. Labelling is aimed at guaranteeing consumers access to complete information on the content and composition of product, help them make the right choice, protect their health and interest. Previous studies have suggested that the information labelled on products can potentially affect decision making, product quality, and price. Product information might lead customers to make the right decisions, although customers often pass over the information due to such reasons as low attention levels and a lack of knowledge about the ingredients. How the message is elucidated and conveyed to customers also depends on various issues such as how the contents of messages are developed. Muller (1985), for instance, questioned whether customers actually use the information noted on their products, in particular regarding foods.

At the same time, adding voluntary additional information may represent a tool to differentiate products and to communicate quality attributes. Nevertheless, the space available on packaging is limited and, therefore, some informa- 
tion cannot be reported even if it is important for consumers (Wolf, Tonsor, \& Olynk, 2011). For these reasons, consumer interest towards food knowledge is growing and an important role is played by information. The theoretical theory at the basis of the researchers' analysis is indeed the economics of information (Akerlof, 1970). More specifically, among the different sources of information available to the consumer, labelling can support customers in making choices connected to their preferences in terms of qualitative features by reducing information asymmetry and, thus, improving economic efficiency.

In industrialized countries, legislation on labelled information that can affect consumers in capturing specific attributes of food products is aimed at avoiding opportunistic behaviour by producers. Indeed, the new EU Regulation No. 1169/2011, published in October 2011, establishes a set of rules concerning mandatory information, nutritional facts and graphical standards for food product labelling in EU. Moreover, different segments of consumers are characterised by different specific needs in terms of information on attributes of food products. In this sense, it is possible to suppose a latent demand for personalized information. Some of these can be reported on the product labels and others can be diffused through alternative tools. The policy for "front of pack labeling" has to be updated and improved constantly since "front of pack labeling" helps consumer understand nutrition facts (Kim \& Kim, 2009). On the other hand, an excess of claims on food packaging can lead to situation of information overloading for consumers. This overloading represents a potential source of noise for consumers, and it may prevent them from making optimal decisions. Time related issues may also deter consumers to carefully read all the information available on food product labels (Nayga, 2000; Drichoutis et al., 2005). As propounded by Elvis, time should be clung to in as much as one is locked in to execute an obligation for an authoritative execution, accomplishments and subsequently exemplifying productivity (Aphu, 2018). It's therefore imperative for clients to take their time in reading the information on the products no matter what their schedules so as not to end up committing the blunder in respect of their purchase decisions.

Over the last decade the interest in issue connected to health and the environment has grown among consumers, impacting their food consumption choices. The problems related to intolerance, allergies, food related diseases, overweight and obesity are rapidly increasing (European Commission 2007). In addition, the consequences of environmental degradation and pollution have increased the awareness of consumers related to the impacts of everyday choices. In deeded, environmental recommendations are gradually assuming a more important role, affecting consumer behaviour regarding food choices. At the same time, in the last fifteen years, food products have been involved in various episodes of food poisoning and scares. The problems related to intolerance, allergies, food consumers are increasingly careful about what they eat, and on the supply side, food companies are adopting strategies aimed at satisfying new market demands connected to food products. Current laws establishing food 
labelling obligations in Ghana have their genesis in a long history of legal provisions dating back to 1888 . The current complement of labelling legislation consists of statutes and subsidiary legislation passed during a span of forty years from 1960 to 2000. The system has evolved through a number of regime changes, economic upheavals and rebirths and bears up well providing a very respectable assembly of food labelling rules which promotes both commercial interests and provides consumer information. The research tends to focus more on product composition on product labels that is the state of customer consciousness in respect of the ingredient that make up a product. From observation and studies undertaken it is realised that very few customers like dieticians and health workers for example pay close attention and if they do understand the implication of the content making up a product. This results in health hazard and conditions like allergies, food poison and gradual reduction of life expectancy rate. Many researches have been conducted in relation to this area of study but have not mostly centred on the product content and their implication to consumer purchase decision. This research seeks to draw consumer's attention to content of products and sensitise beneficiaries to develop a positive attitude and be passionate regarding the subject matter.

\subsection{Statement of the Problem}

With the increasing demand in consumable goods, there has been a consequent flooding of the market with products from different origins, ranging from different companies across the world. It's worth noting that this has been the situation, most consumers have not adopted behavioural traits to analyse the attribute of product they consume daily. Over the years it is realised that most customers are not conscious of the ingredient that constitute the product bought. Despite the effort made by food and drug authorities and other related bodies to insist on labelling most importantly stipulating ingredient constituting a product, the attitude consumers carry is still nothing to write home about. The irony with customer's unconcerned attitude is that much information is made available on most approved food products. This is attributed to laziness of most customers who feel very reluctant to read the composition of product. The general perception is that once a product is packaged it is good enough to be consumed. This forms part of the challenges propelling this research. Furthermore, most consumers repose their trust in family and friends when it comes to purchasing and consumption of products. This undue influence of the personalities tends to be a reason for the negligence of customers.

Objectively, to explore the level of consciousness of product content inscription among respondent, to ascertain the importance respondents attach to product content inscription labelled on product. To determine respondents understanding of product content inscription on product and to establish actions taken by customers who become aware of product contents inscribed on the product. 
What is the level of consciousness of product content inscription among respondent? What importance do respondent attach to product content inscriptions labelled on products? Do respondents understand product content inscription on products? What actions do respondents take when they become aware of product content inscription on products? The above are the research questions.

Significantly, the study provides consumers with information on the ingredients that make up of a product that will aid consumers to make conscious choices when purchasing consumer goods with respect to their health status and needs. Food Content information is very important for people who are on special diet or with food related health problems and diseases such as obesity, diabetics, cardiovascular diseases and various types of cancers as it helps them to make informed choices of food (Washi, 2012). The study will also help Manufacturers use labelling information to market their products whereas consumers use the information in making informed food choices. A study by Miles et al. (2010) in Poland revealed that consumers drew the knowledge on food from different sources of the mass-media but in their opinion the most important sources providing the broadest information about products are labels. Also, time is of great importance regarding clients checking inscriptions on any product before they take a purchase decision so as not to experience any cognitive dissonance. This is evidenced by Aphu et al. (2015) if you inject time as an antidote in your daily dealings, you will always have healthy moments cum fruitful results. Therefore, time ought to be adhered to in as much as recruitment and selection are of great concern in an organizational performance, achievements and thereby encapsulating productivity. This depicts how valuable it is to make decisions in respect of time so as not to be found wanting at the eleventh hour.

\subsection{Study Area}

A concise History about Ho.

Ho is the capital city of the Ho Municipal District and the regional capital of Volta Region, Ghana. The city lies between Mount Adaklu and Mount Galenukui or Togo Atakora Range, and is home to the Volta Regional Museum, a cathedral, and a prison. It was formerly the administrative capital of British Togoland now part of the Volta Region.

Ho was part of the German colony of Togoland until World War I, when it was occupied by the British. Ho later became the capital of the League of Nations mandate of British Togoland and then French Togoland until that entity's incorporation into the British Gold Coast colony, which subsequently became Ghana. The town was initially inhabited by the people of Hegbe (now Heve), followed by the people of Banakoe (now corrupted to Bankoe). These two groups lived alongside each other with individual chiefdoms.

The first known chief of the Bankoe people was Afede Asor I, known in his private life as Akorli. The chief of Heve was Anikpi I, who was known in his private life as Adzah Doe. The Ahoe and Dome joined the settlement at a later stage but came to play leading roles in its development. The people of Dome 
became the ruling class until the emergence of modern-day chieftaincy which they ceded to the Bankoe people. The people of Hliha are a sub-group of Bankoe.

The Ho town was the area of study (See Figure 1 and Figure 2). It involved lecturers, students, administrative workers, traders etc. Also the research was based on packaged processed food. The sel0ected area was appropriate for gathering information or data due to the caliber of people involved. It brought on board people from various age groups making the findings of the research more realistic and unbiased. Ho has a population of 192,871 with 94,951 males and 971,920 females with the majority of peeled encaging in private small businesses and indigenous agriculture. Most employed persons are in the public sector. Ho has five tertiary institutions and about ten senior high schools. In addition it hosts referral Hospital and the municipal Hospital with over ten Hotels in two and three star classification(s). There are about four recognizable shopping centers where the middle and to high income earners purchase their consumables.

\section{Review of Literature}

According to Hieke \& Taylor (2012), Food labelling enables consumers to make informed decisions when purchasing and consuming food products. Consumption of packaged food items has grown tremendously in the recent past. Despite this, the issue of consumer awareness about usage of food labelling information has attracted little research attention in developing countries. Food regulations and increased consumer awareness are forcing packaged food companies across the world to display more and more information on packaged food products. However, little is known about consumer response to such information in emerging economies. Product content inscription basically looks at the ingredients that are used in producing a particular product and later on placed on the product to inform the costumers about what went in, in the production of such a product. In retrospect to the past, Food and Drugs authority demand that all

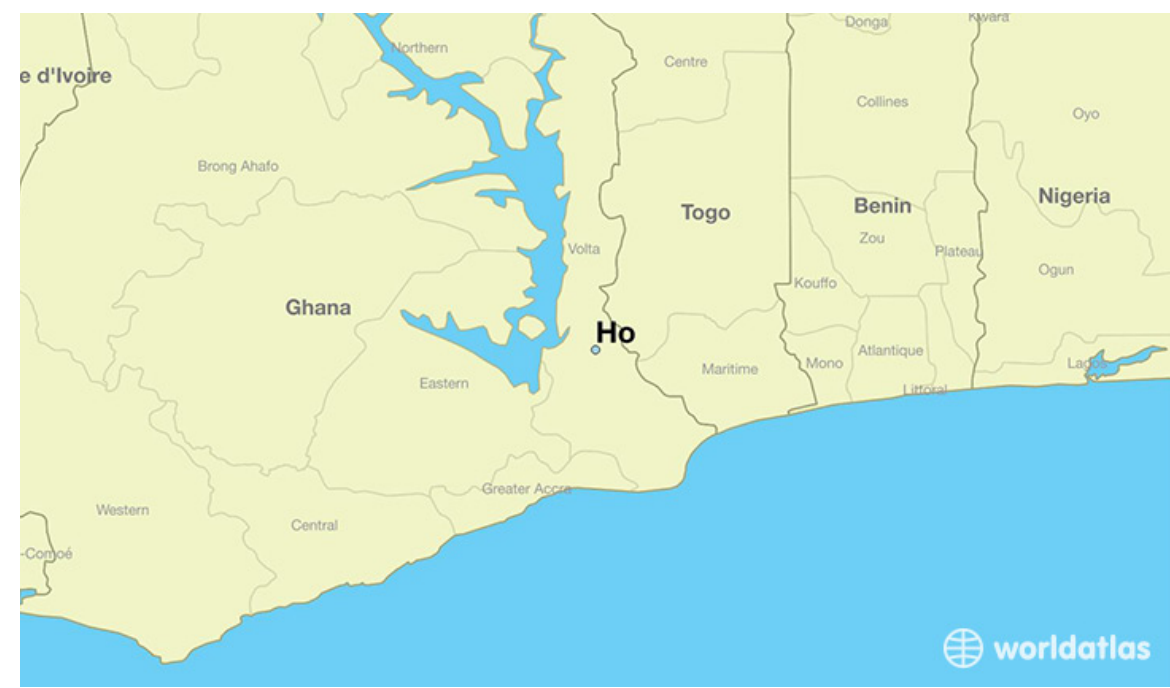

Figure 1. World atlas showing the location of Ho. 


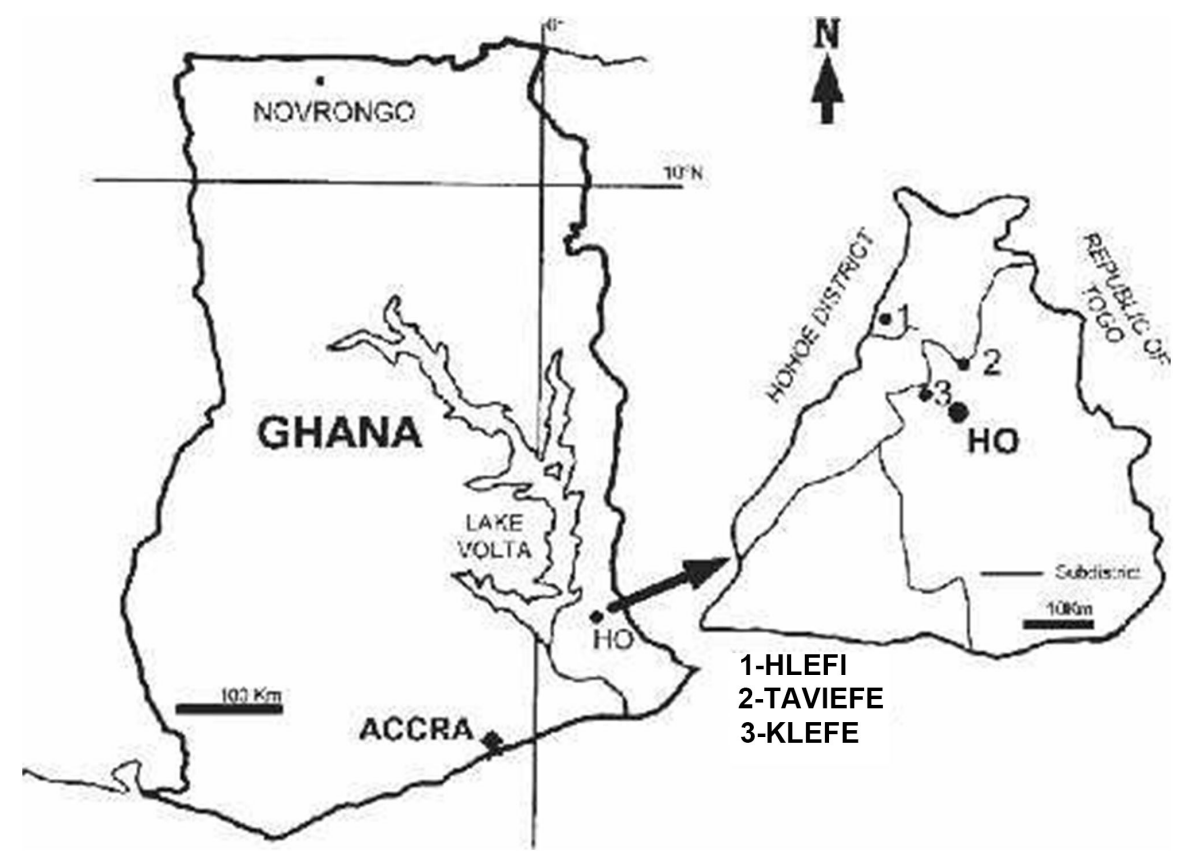

Figure 2. Location of Ho on the Ghana Map Leading to the direction of Ho coupled with its Environs.

products and most importantly food items should have the makeup of the product well inscribed on them. The food and drugs board regulates the safety of substances added to food.

\subsection{Packaging and Labelling}

Results clearly indicates that there is a strong association of packaging as more than $70 \%$ consumers stated that they believe on packaging to facilitate their decision-making process at the (point of Purchase) POP (Wells et al., 2007). The results show that the graphics on packaging of the label can highly influence purchase intentions and attribute beliefs due to their attraction. This suggests that graphical information could be misleading and affect the consumer's buying behaviour. Consumers buy products by mistake believing them to be a different product due to its similar packing. People like to purchase a product that is in similar packaging to a well-reputed brand than another product at the same price, which is in more distinct packaging. One of the issues, which seems to be disregarded in determining the value added through packaging seems controversial in many sectors. On the other hand, some sectors like cosmetics, packaging design and materials can easily become a crucial part of the value of product. Most important Package design attribute that counts in terms of healthiness expectations is the package's shape and visibility of the product through the Package. The visual dimension of food packaging matters because it transfers undercover messages; healthiness is one of them. A colour used on packaging greatly impacts the perception of the consumer. Shoppers judge the product attributes by the colour on its packaging (Aphu, 2018). Packaging has a direct impact on 
the children's preferences Also, due to the attractive packaging specially the presence of cartoon heroes on packaging, there is increase in their interest in the purchase of unhealthy foods. The children try to influence their parent's decisions during shopping. Packaging has a positive impact on consumer buying behaviour. However brand image is a mediating variable in the relationship of consumer buying behaviour and packaging (Sial et al., 2018). Packaging among the $4 \mathrm{ps}$ of Marketing is a very powerful tool, its impact reaches deep in consumers mind as compared to advertising. Even at the point of purchase it is packaging that influences the buying decision and dominates a product over its competitors. Packaging creates a positive perception on the consumers and can even result in brand switching in case of children (Méjean, Macouillard, Péneau, Hercberg, \& Castetbon, 2013).

Labelling formats have been defined by guidance and legislation in every country. In Ghana, the labeling requirement is based on the Codex Alimentarius Standards (1985). Per this standard, products are to bear "appropriate information to ensure that adequate and accessible information is available to the next person in the food chain to enable them to handle, store, process, prepare and display the product safely and correctly and a lot or batch number available for easy identification and recall if necessary".

According to the Food Law in Ghana (PNDC L 305B), it is an offence to offer for sale food that is not of nature, substance and or quality. Amidst this laws and the benefits of labels, the shelves of both small and big stores and supermarkets are washed with unwholesome products (expired, unlabeled, badly labeled, non-certified and products labeled in different languages other than English, the official language of Ghana), which are being confiscated by Ghana Standard Board (GSB) and burnt/destroyed almost every week in the clear view of the public. While readings and understanding of products labels is important for preventing health hazards issues, it is a common perceived knowledge in Ghana that most consumers do not 1) read and 2) even those who read do not understand the labelling information's put on products mainly for several reasons.

The question that needs to be asked is, do Ghanaian consumers read labels and understand it regarding the choice and usage of information on product label? The purpose of this study is therefore to ascertain the label reading habits of consumers and determined how labels affect the choice and usage of product.

\subsection{Perspective to Product Content and Labelling}

Consumers' buying decision is very complex. Usually purchasing intention is related with consumers' behaviour, perception and their attitude. Purchase behaviour is an important key point for consumers during considering and evaluating of certain product (Keller, 2001). Purchase intention is an effective tool use in predicting purchasing process. Once the consumers decide to purchase the product in certain store, they will be driven by their intention. However, purchase intention might be altered by the influence of price, quality perception and 
value perception (Aphu \& Adator, 2018).

In addition, consumers will be interrupted by internal impulse and external environment during purchasing process. Their behaviour will be driven by the physiological motivation that stimulates their response, which brings them to the retail store to fulfil their need (Kim et al., 2001). With respect to inscriptions on food products, several studies have been carried out in the past to determine the consumers' motivation, perception, preference and behavior on food products (Beneke, 2008; Boutsouki et al., 2008). There is only one study on consumers' intention of buying own label premium food products, which guided the present study.

Today's consumer are said to be king of the modern market. Nevertheless, in reality most companies but not all treat consumers very badly. The consumer is cheated in different ways by middlemen, the forms of exploitation may be like adulteration, under-weight of goods, selling goods of inferior quality \& duplicated goods, charging higher prices, misleading advertisement in the media etc., the consumer is not sure of getting qualitative goods manufactured \& preserved in hygienic condition and at competitive prices (Kumar, 2016).

Most companies in Ghana are aware of the law governing regulations on product contents, apparently, there are still a number of products in the markets that have no information pertaining to the ingredients composure of products. What informs the decisions of some who inscribe the contents on their labels tends to be the regulations requirements.Also the orientation of the company to sensitize their customers on the identity of the product they tend to purchase. Argument have been done in the recent past in the united states claiming companies that produce genetically modified products should label the product in order for them to know what makes up the product. Many due this argument, who don't want to lose the customers tend to label their product to maintain or develop their relationship with their customers.

Internationally when trying to send your products outside its jurisdiction there are standards that must be followed due this most companies seeking for wider markets, makes sure they meet the standard. Companies that do not attach much prominence to the ingredient speculation on their product are most unaccredited companies such as local manufactures for example "Sobolo, Liha, Ice, Kenkey, Asana and etc" (local beverages in Ghana).

As the number of diet related problems increases from time to time, consumers nowadays are very health Conscious about their diet especially in Malaysia. Nutritional labelling may guide them to assist the food choice. It provides and conveys a lot of information especially nutrient content to the consumers. Living in the urbanized worlds these days, consumers have been taking seriously the role of nutrition in their life where it started with the awareness of nutrition in food and reading the nutrition labelling. The increasingly educated consumers and their awareness is a big help to the nutritional labelling in the world. There is increasing concern on the diet-related health problems and nutritional sub- 
stances that have been the necessary acceptance attributes for consumers to purchase a product. This shows that consumers in these day and age are alert on how important the nutritional labelling for them to know what they are consuming every day (Khan et al., 2017). Though some customers have attach some importance to product composition due to the rising issues regarding health others are left in blue. Researches that have been conducted by some researcher's reveals some customers don't really attached importance to the composition of product due to some factors for example being interested in the product and less concerned about what makes it up.

\section{Methodology}

The research methodology describes how information was collected by the researchers. It also states the population of the study area and the justification of approaches. It therefore covers research design under which population and sample size, sampling methods were harmonized, data collection method and challenges as well as data analysis method.

\subsection{Research Design}

This research was exploratory in nature and so used descriptive research design technique by employing by identifying and illustrating the characteristics of the research phenomenon which takes the form of a single cross sectional research design. The term descriptive research refers to the type of research question, design, and data analysis that will be applied to a given topic. Descriptive research can be either quantitative or qualitative. It can involve collections of quantitative information that can be tabulated along a continuum in numerical form, such as scores on a test or the number of times a person chooses to use a-certain feature of a multimedia program, or it can describe categories of information such as gender or patterns of interaction when using technology in a group situation. Descriptive research involves gathering data that describe events and then organizes, tabulates, depicts, and describes the data collection. It often uses visual aids such as graphs and charts to aid the reader in understanding the data distribution. Because the human mind cannot extract the full import of a large mass of raw data, descriptive statistics are very important in reducing the data to manageable form.

When in-depth, narrative descriptions of small numbers of cases are involved, the research uses description as a tool to organize data into patterns that emerge during analysis. Those patterns aid the mind in comprehending a qualitative study and its implications. The population for the research comprises of consumers of convenience goods living in the Ho town who normally purchase at the shopping center. Hundred (100) customers of the recognized shopping centers were selected from the population to be the sample size. The sampling method that was used in this research was the Convenience sampling. The convenience sampling is referred to as accidental sampling, haphazard sampling and 
opportunity sampling. This refers to the situation where the researcher meet people unexpectedly on the field.

\subsection{Data Collection Method and Challenges}

In order to collect reliable and valid information, the researcher contacted various groups of people who normally purchase at the shopping center Ho. The main tool that was used in collecting primary data is a structured questionnaire, which was based on closed-ended questions. The closed-ended questions facilitate easy processing of the answers and enhanced the comparability of the answers. Most importantly, closed-ended questions are easy for respondents to complete, precisely because respondents are not expected to write extensively but ticks or circle answers, and also quicker to complete. This is very appropriate because many respondents do not seem to have time for researchers and thus not prepared to spend more time in answering questions. Questionnaires are also an efficient instrument because they provide anonymity and make it easier to collect large volumes of data from a target response group who are scattered geographically. Due to time constraints, the lecture hours made it difficult to get the appropriate sample size for the research. Unwillingness to provide true responses to questionnaires, some respondents were in a hurry to go and perform other duties made it difficult to give true response. Because of the inability to understand question perhaps due to illiteracy, some respondents were not able to understand certain questions with relation to the questionnaire refuse to fill them. Because of respondent fatigue in the course of administering the questionnaire, some respondents were not in a good mood which made them refuse to fill the questionnaire.

\subsection{Data Analysis Method}

The data was organized into charts, percentages and figures based on the questionnaires given to the respondents. The results were subsequently computed into percentages. Diagrammatic representations of the statistical summaries of the result were done where necessary in the form of pie charts, graphs and frequency tables. Computer data analysis such as Statistical Package for the Social Sciences (SPSS) will be employed to analyze the data in order to help interpret results.

\section{Discussions}

This chapter presents the findings and results based on the methodology employed in chapter three. It further presents results of data collected and analysis from the questionnaires in relation to customer consciousness of product content on product labels. Data was discussed in relation to specific objectives to prove or confirm the given information.

\subsection{Demographic Factors}

From Table 1, it appears that the distribution of sex of the respondents is quite 
evenly spread among the sex distribution of the respondents. This means that the findings of the research are greatly influenced by Male and Female respondents regarding to customer consciousness of product content on product labels.

The distribution of respondents by age is skewed towards $20-29$ years with $77 \%$ of the respondents, $21 \%$ of the respondents are between the ages of $30-31$ whiles the rest $2 \%$ of the respondent age are between $40-49$. This means that the responses of this questionnaire are greatly influenced between the ages of 20 - 29 (See Table 2 and Figure 3).

Most of the respondents were students, covering the majority of $67 \%, 28 \%$ of the respondents were Nurses, $4 \%$ were traders and $1 \%$ of the respondents is a Lecturer in the institution (See Table 3 and Figure 4).

There is a significance difference between the proportion of those who agree or strongly agree, and other groups, with those who agree or strongly agree being significantly less than 0.5 of the population.

Null hypothesis, they do not have knowledge on labels

Hypothesis, they have knowledge on product labels

Alpha $=0.5$

From the binomial test of Table 4 there is $95 \%$ confidence interval that there exit a significant difference against standard

\subsection{Knowledge of Product Label Table}

$\mathrm{X} 1=\mathrm{I}$ usually buy labelled product

$\mathrm{X} 2$ = I know of labels on products

$\mathrm{X} 3$ = I always check on labels on product before purchase

$\mathrm{X} 4=\mathrm{I}$ take every information on labels with seriousness

$\mathrm{X} 5$ = I read every inscription label before I purchase

$\mathrm{X} 6=$ Most process product made in Ghana are well labelled

$\mathrm{X} 7=\mathrm{I}$ 'm aware of all the product labelling features on product packaged

$\mathrm{X} 8=\mathrm{I}$ 'm able to read and understand the product ingredient composition of a product.

X9 = I spend some time examining the product ingredient before purchase

$\mathrm{X} 10=\mathrm{I}$ do not buy product that I do not know the ingredients that make them up.

$\mathrm{X} 11$ = I always advice people to check the ingredient of the product they are about consuming.

$\mathrm{X} 12=$ Once a product is packaged and sold in the market I deem it fit to buy.

Table 1. Sex distribution of the respondents.

\begin{tabular}{ccc}
\hline Sex & Frequency & Percent \\
\hline Male & 52 & 52 \\
Female & 48 & 48 \\
Total & 100 & 100 \\
\hline
\end{tabular}

Source: Field Data, August 2018. 
Table 2. Age distribution of the respondents.

\begin{tabular}{ccc}
\hline Age & Frequency & Percent \\
\hline $20-29$ & 77 & 77 \\
$30-39$ & 21 & 21 \\
$40-49$ & 2 & 2 \\
Total & 100 & 100 \\
\hline
\end{tabular}

Source: Field Data, August 2018.

Table 3. Occupation of the respondents.

\begin{tabular}{ccc}
\hline Occupation & Frequency & Percent \\
\hline Students & 67 & 67 \\
Lecturers & 1 & 1 \\
Nurses & 28 & 28 \\
Traders & 4 & 4 \\
Total & 100 & 100 \\
\hline
\end{tabular}

Source: Field Data, August 2018.

Table 4. Show Binomial Test of the customer knowledge of product labels.

\begin{tabular}{|c|c|c|c|c|c|c|}
\hline & & Category & $\mathbf{N}$ & Observed Prop. & Test Prop. & Exact Sig. (2-tailed) \\
\hline & Group 1 & $\leq 3$ & 13 & 0.13 & 0.5 & 0.00 \\
\hline \multirow[t]{3}{*}{$\mathrm{X} 1$} & Group 2 & $>3$ & 87 & 0.87 & & \\
\hline & Total & & 100 & 1 & & \\
\hline & Group 1 & $\leq 3$ & 8 & 0.08 & 0.5 & 0.00 \\
\hline \multirow[t]{3}{*}{$\mathrm{X} 2$} & Group 2 & $>3$ & 92 & 0.92 & & \\
\hline & Total & & 100 & 1 & & \\
\hline & Group 1 & $\leq 3$ & 12 & 0.12 & 0.5 & 0.00 \\
\hline \multirow[t]{3}{*}{$\mathrm{X} 2$} & Group 2 & $>3$ & 88 & 0.88 & & \\
\hline & Total & & 100 & 1 & & \\
\hline & Group 1 & $\leq 3$ & 11 & 0.11 & 0.5 & 0.00 \\
\hline \multirow[t]{3}{*}{$\mathrm{X} 4$} & Group 2 & $>3$ & 89 & 0.89 & & \\
\hline & Total & & 100 & 1 & & \\
\hline & Group 1 & $\leq 3$ & 22 & 0.22 & 0.5 & 0.00 \\
\hline \multirow[t]{3}{*}{$\mathrm{X} 5$} & Group 2 & $>3$ & 78 & 0.78 & & \\
\hline & Total & & 100 & 1 & & \\
\hline & Group 1 & $\leq 3$ & 27 & 0.27 & 0.5 & 0.00 \\
\hline \multirow[t]{2}{*}{$\mathrm{X} 7$} & Group 2 & $>3$ & 72 & 0.72 & & \\
\hline & Total & & 99 & 1 & & \\
\hline
\end{tabular}

Source: Field Data, August 2018. 


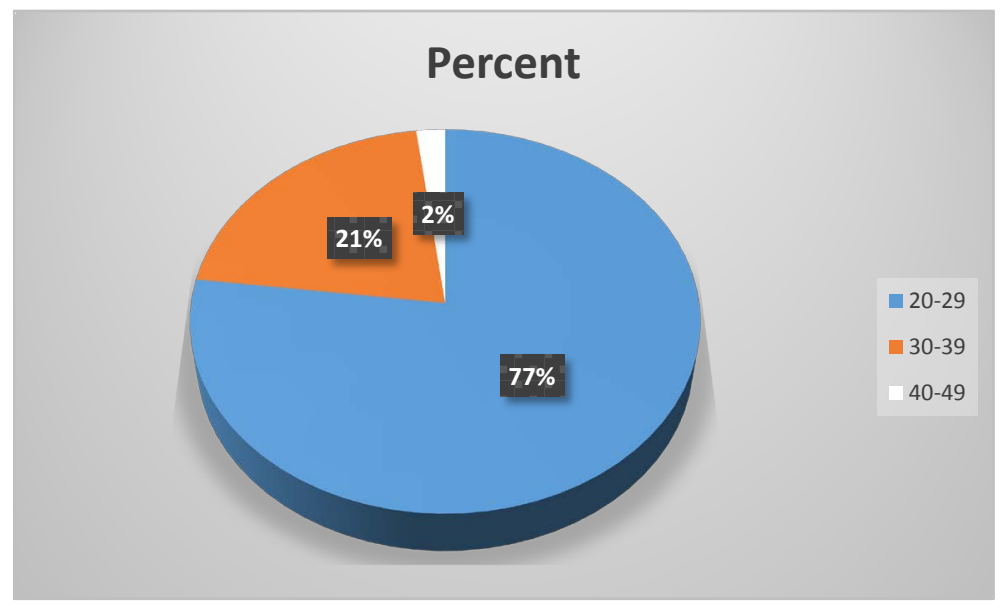

Figure 3. Age distributions of respondents. Source: Field Data, August 2018.

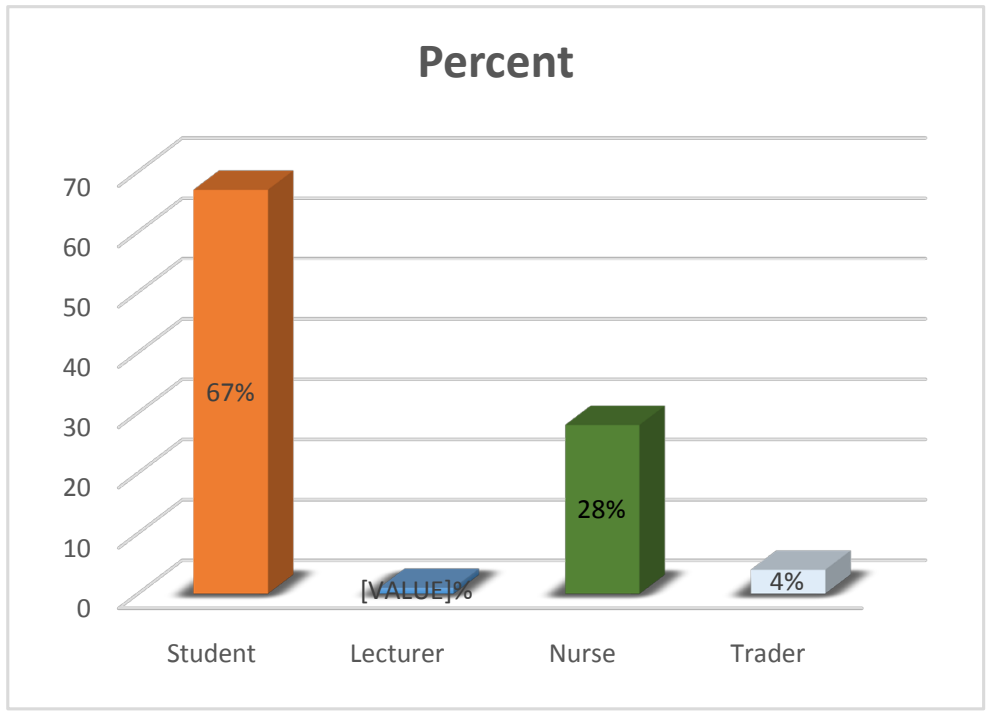

Figure 4. Distribution of respondents' occupations. Source: Field Data, August 2018 .

$\mathrm{X} 13=\mathrm{I}$ research about the ingredient composition to find out what they are and their effect on the body

$\mathrm{X} 14=\mathrm{I}$ check the ingredient of the product before purchasing and consumption

$\mathrm{X} 15=\mathrm{I}$ check the ingredient of the product during consumption

$\mathrm{X} 16=\mathrm{I}$ check the product ingredient after consumption of the product

$\mathrm{X} 17$ = I don't check at all the ingredient composition of the product

$\mathrm{X} 18=$ Am always advice by friends and peers to never consume a product without not checking the ingredient

X19 = I have experienced certain health implication (e.g. allergies) related to consumption of certain product whose contents I was ignorant about.

$\mathrm{X} 20=\mathrm{I}$ witnessed people experience certain health implication (e.g. allergies) related to consumption of certain product whose contents they were ignorant 
about.

From Table 5, the indicator $\mathrm{x} 8$ shows that $70 \%$ of the respondents agree that they are able to read and understand the ingredient composition of the product. $8 \%$ of the respondents are undecided on the subject matter whiles the rest of the $22 \%$ disagree with the proposition.

Relating to spending some time examining the product before purchase as an $\mathrm{x} 9$ indicator, $61 \%$ of the respondents agree that they spend time examining the product, $13 \%$ were undecided and $26 \%$ disagree to the proposition that they do not exam the product.

Out of our sample size thus 100 with relation to the X10 indicator $60 \%$ of the respondent agree to the fact that they do not buy product whose ingredient composition they are not aware of, $17 \%$ were undecided and $23 \%$ disagreed to the assertion. Again, out of the 100 respondent $64 \%$ agree to the fact that they always advice people to check the ingredient of the product with relation to indicator X11, 14\% were undecided and $22 \%$ disagree to the assertion that they do not advice people to check the ingredient of the product they are about consuming

As illustrated above, in $\mathrm{X} 12,42 \%$ of respondents agree that once a product is packaged and sold in the market they deem it fit to buy, however $10 \%$ are undecided and $47 \%$ disagree (See Table 6).

Furthermore, 64\% hold on in agreement to the assertion that they research about the ingredient composition to look out for the effect on the body. On the contrary however $11 \%$ are undecided and $23 \%$ are against the assertion.

Pertaining to checking the ingredient of the product before purchasing and consumption $65 \%$ agree whereas $11 \%$ are undecided and $23 \%$ are disagreed.

Table 5. Awareness of product content inscription on product.

\begin{tabular}{cccc}
\hline & & Frequency & Percent \\
\hline \multirow{2}{*}{ X8 } & Agree & 70 & 70.0 \\
& Undecided & 8 & 8.0 \\
Disagree & 22 & 22.0 \\
Xgree & Undecided & 61 & 61.0 \\
& Disagree & 13 & 13.0 \\
X10 & Agree & 26 & 26.0 \\
& Undecided & 60 & 60.0 \\
& Disagree & 17 & 17.0 \\
& Agree & 23 & 23.0 \\
& Undecided & 64 & 64.0 \\
& Disagree & 14 & 14.0 \\
& & 22 & 22.0 \\
\hline
\end{tabular}

Source: Field Data, August 2018. 
Table 6. Checking for inscriptions of product content.

\begin{tabular}{|c|c|c|c|}
\hline & & Frequency & Percent \\
\hline & Agree & 42 & 42.0 \\
\hline \multirow[t]{3}{*}{$\mathrm{X} 12$} & Undecided & 10 & 10.0 \\
\hline & Disagree & 47 & 47.0 \\
\hline & Agree & 65 & 64.0 \\
\hline \multirow[t]{3}{*}{$\mathrm{X} 13$} & Undecided & 11 & 11.0 \\
\hline & Disagree & 23 & 23.0 \\
\hline & Agree & 65 & 65.0 \\
\hline \multirow[t]{3}{*}{ X14 } & Undecided & 11 & 11.0 \\
\hline & Disagree & 23 & 23.0 \\
\hline & Agree & 63 & 63.0 \\
\hline \multirow[t]{3}{*}{ X15 } & Undecided & 13 & 13.0 \\
\hline & Disagree & 24 & 24.0 \\
\hline & Agree & 47 & 47.0 \\
\hline \multirow[t]{3}{*}{ X16 } & Undecided & 10 & 10.0 \\
\hline & Disagree & 43 & 43.0 \\
\hline & Agree & 36 & 36.0 \\
\hline \multirow[t]{3}{*}{ X17 } & Undecided & 10 & 10.0 \\
\hline & Disagree & 53 & 53.0 \\
\hline & Agree & 55 & 55.0 \\
\hline \multirow[t]{3}{*}{ X18 } & Undecided & 7 & 7.0 \\
\hline & Disagree & 37 & 37.0 \\
\hline & Agree & 47 & 47.0 \\
\hline \multirow[t]{3}{*}{ X19 } & Undecided & 12 & 12.0 \\
\hline & Disagree & 40 & 40.0 \\
\hline & Agree & 67 & 67.0 \\
\hline \multirow[t]{2}{*}{$\mathrm{X} 20$} & Undecided & 6 & 6.0 \\
\hline & Disagree & 26 & 26.0 \\
\hline
\end{tabular}

Source: Field Data, August 2018.

$63 \%$ of the respondents agree that they check the ingredient composition of the product they consume during consumption on the other hand $13 \%$ are undecided and the rest of the $24 \%$ disagree.

Indicator X16 reveals that $47 \%$ agree that they check the product content inscription after consumption meanwhile $10 \%$ stand undecided with the remaining $43 \%$ disagreeing.

Following the sequence, indicator X17 suggests that $36 \%$ of the respondents don't check on product content inscription $10 \%$ are undecided and 53\% disagree.

$55 \%$ of our respondents hold on in agreement that they are always advised by friends and peers to check product content inscriptions however $7 \%$ are unde- 
cided and $37 \%$ disagree.

At indicator X19, 47\% agree that they have experienced certain health implications related to consumption of certain products whose content they were ignorant about whiles $12 \%$ and $40 \%$ are undecided and disagree respectively.

Finally, at indicator X20,67\% agree that they have witnessed people experience certain health implications related to consumption of certain product whose contents they were ignorant about whiles $6 \%$ are undecided and $26 \%$ disagree to this statement.

\subsection{Summary of the Findings}

The research indicates that, out of the hundred respondent which were involved in the study, using the statistical tool known as binomial test. Majority indicated that they have knowledge of product labels. This is indicated in 0.5 of the respondent agreeing to the assertion that they have knowledge of product labels. Thus a significant section of the sample size is not ignorant of product labels. Majority of the respondent have knowledge about the product content inscription. The research indicated that majority spend some time examining the ingredient composition and also try to educate their friends or people around them in respect of the importance of checking the product composition. Majority agree that they don't buy product that do not contain product inscription. The research reveals based on the figurative analysis that minority buy any product that is packaged. The majority disagree to the proposition that once a product is packaged it is fit to buy. Majority do check product content inscription before, during and after consumption of the product.

\section{Conclusion and Recommendations}

\subsection{Recommendations}

Future researchers undertaking similar researches, the sample size should be made up of not only educated people who have reached tertiary level but should embrace those with lesser qualifications and the uneducated likewise. To the minority who are undecided and disagree to the assertion that they have knowledge about product labels, we suggest that health regulatory bodies, National Commission for Civic Education, should take up a mantle to make the public aware, for instance, social media, print media, telecommunication media. The researchers recommend that Product manufacturers should endeavor to inscribe the contents of products on their labels and encourage their customers to read through their advertisements. Various institutions like Chartered Institute of Marketing Ghana and Association of Ghana Industries should impress on corporate institutions to inscribe product content visibly on the product. In the nutshell, the researchers recommend that, various wholesalers \& retailers should distribute only products that meet labelling standards and educate customers of product contents. 


\subsection{Conclusions}

All in all, in contradiction to the perception that people do not pay attention to content inscriptions on product labels, this research has revealed that customers have a positive response towards the subject matter and always checks for product content inscription before they purchase or consume a product. Customers are therefore conscious of product content inscriptions on product labels because they have been educated to read labels before purchase and before consumption as product ingredients could be harmful to their health and thereby not experiencing a situation of cognitive dissonance.

\section{Conflicts of Interest}

Authors have vehemently declared that no competing interests exist.

\section{References}

Akerlof, G. A. (1970). The Market for "Lemons": Quality Uncertainty and the Market Mechanism. The Quarterly Journal of Economics, 84, 488-500. https://doi.org/10.2307/1879431

Aphu, E. S. (2015). The Study of Time Management in Civil Service Institutions in Ghana: A Case of Accra Metropolitan Assembly. European Journal of Business and Management, 7, 173-190.

Aphu, E. S. (2018). Building Image in the Airline Industry. Pakistan International Airline as the Point of Convergence. International Journal of Recent Advances in Multidisciplinary Research, 5, 3830-3834.

Aphu, E. S. (2018). The Impact of Recruitment and Selection Criteria on Organizational Performance. GN Bank, Greater Accra Region of Ghana as the Mirror. Journal of Public Administration and Governance, 8, 283-296.

Aphu, E. S., \& Adator, S. W. (2018). Challenges and Sustainable Development of Small and Medium-sized Enterprises: Evidence from a Local Processing Company in Ghana (Nkulenu). Advances in Social Sciences Research Journal, 5, No. 5. https://doi.org/10.14738/assrj.55.4572

Beneke, J. (2008). Consumer Perceptions of Private Label Brands within the Retail Grocery Sector of South Africa. Journal of Business Management, 4, 203-220.

Boutsouki, C., Zotos, Y., \& Masouti, Z. (2008). Consumer Behavior towards Own Label: Monitoring the Greek Experience. Agricultural Economic Review, 9, 81-92.

Hieke, S., \& Taylor, C. R. (2012). A Critical Review of the Literature on Nutritional Labeling. Journal of Consumer Affairs, 46, 120-156. https://doi.org/10.1111/j.1745-6606.2011.01219.x

Keller, B. (2001). Consumer Testing of the Acceptability and Effectiveness of Front-of-Pack Food Labelling Systems for the Australian Grocery Market. Health Promotion International, 24, 120-129. https://doi.org/10.1093/heapro/dap012

Khan, S., Siddique, R., Sajjad, W., et al. (2017). Biodiesel Production from Algae to Overcome the Energy Crisis. HAYATI Journal of Biosciences, 24, 163-167. https://doi.org/10.1016/j.hjb.2017.10.003

Kim, S.-Y., Nayga Jr., R. M., \& Capps Jr., O. (2001). Food Label Use, Self-Selectivity, and Diet Quality. Journal of Consumer Affairs, 35, 346-363. 
https://doi.org/10.1111/j.1745-6606.2001.tb00118.x

Kim, W. K., \& Kim, J. (2009). A Study on the Consumer's Perception of Front-of-Pack Nutrition Labeling. Nutrition Research and Practice, 3, 300-306.

https://doi.org/10.4162/nrp.2009.3.4.300

Kumar, M. V. (2016).

http://www.kumarrobotics.org/wp-content/uploads/2016/07/VijayKumar_CV_July_20 16.pdf

Méjean, C., Macouillard, P., Péneau, S., Hercberg, S., \& Castetbon, K. (2013). Perception of Front-of-Pack Labels According to Social Characteristics, Nutritional Knowledge and Food Purchasing Habits. Public Health Nutrition, 16, 392-402. https://doi.org/10.1017/S1368980012003515

Miles, L. K., Karpinska, K., Lumsden, J., \& Macrae, C. N. (2010). The Meandering Mind: Vection and Mental Time Travel. PLoS ONE, 5, e10825.

https://doi.org/10.1371/journal.pone.0010825

Sial, et al. (2018) Neoproterozoic Successions of the São Francisco Craton, Brazil. https://www.sialparis.com/

Washi, S. (2012). Awareness of Food Labeling among Consumers in Groceries in Al-Ain, United Arab Emirates. International Journal of Marketing Studies, 4, 38. https://doi.org/10.5539/ijms.v4n1p38

Wells, L. E., Farley, H., \& Armstrong, G. A. (2007). The Importance of Packaging Design for Own-Label Food Brands. International Journal of Retail \& Distribution Management, 35, 677-690.

https://www.researchgate.net/publication/228348037_The_importance_of_packaging design_for_own-label_food_brands.

Wolf, C. A., Tonsor, G. T., \& Olynk, N. J. (2011) Understanding U.S. Consumer Demand for Milk Production Attributes. Journal of Agricultural and Resource Economics, 36, 326-342. https://www.jstor.org/stable/23243084 